\title{
Microsatellite DNA markers for Lysiphlebus testaceipes
}

\author{
XAVIER FAUVERGUE, ${ }^{*}$ CÉDRIC TENTELIER, ${ }^{*}$ GWENAËLLE GENSON,+ PHILIPPE AUDIOT,+ \\ THOMAS GUILLEMAUD* and RÉJANE STREIFF† \\ *Unité Mixte de Recherche 1112 Réponse des Organismes aux Stress Environnementaux, Institut National de la Recherche \\ Agronomique - Université Nice Sophia Antipolis, 400 route des Chappes, BP 167, 06903 Sophia Antipolis Cedex, France, +Centre de \\ Biologie et Gestion des Populations, Institut National de la Recherche Agronomique, Campus International de Baillarguet, CS 30016, \\ 34988 Montferrier sur Lez Cedex, France
}

\begin{abstract}
Microsatellite loci were isolated from the aphid parasitoid Lysiphlebus testaceipes (Hymenoptera: Braconidae). Ten loci were obtained from an enriched partial genomic library. Genetic diversity was analysed at seven of these loci and two natural populations, one on oleander and one on citrus. The observed number of alleles ranged from one to 17, and the observed heterozygosity ranged from 0.37 to 0.82 . In both populations, no departure from Hardy-Weinberg equilibrium was detected except for one locus. The differentiation between the two populations was characterized by an $F_{\mathrm{ST}}$ of 0.09 .
\end{abstract}

Keywords: Lysiphlebus testaceipes, microsatellite, parasitoid, Braconidae, enriched library

Lysiphlebus testaceipes (Cresson) is a solitary parasitoid whose host range reaches more than 100 aphid species on numerous plants (Pike et al. 2000). It was introduced from Central America to southern France during the 1970s to control populations of various aphid species. It then spread rapidly all over Mediterranean Europe (Starý et al. 1988). The wide host range and geographical distribution of L testaceipes raise questions about the individual processes of dispersal and the resulting population genetic structure. To address these issues, we developed a set of 10 microsatellite loci whose variability was analysed on two samples of L. testaceipes collected on oleander and citrus in southeastern France.

Genomic DNA was isolated from a pool of 50 frozen Lysiphlebus testaceipes following standard procedure (Sambrook et al. 1989) and digested with RsaI. A 3001000 bp fraction of the digested DNA was selected on agarose gel, purified and ligated to RsaI linkers. The enrichment procedure followed the protocol from Kijas et al. (1994) based on streptavidin-coated magnetic particles (Magnesphere, Promega), with slight modifications. A 5'-biotinylated (CT) and $(\mathrm{GT})_{10}$ oligonucleotides were used as probes. The enriched single stranded DNA was amplified using one of the RsaI linkers as primer to recover double stranded DNA. The PCR (polymerase chain reaction) products were

Correspondence: Xavier Fauvergue. E mail: fauverg@antibes.inra.fr purified and ligated into pGEM-T Easy vector (Promega), and the plasmid transformed into Escherichia coli supercompetent cells (XL1 blue, Stratagene). Individual E. coli colonies were transferred to a positively charged Hybond$\mathrm{N}+$ (Amersham) membrane. DNA was fixed on the membrane by baking at $80{ }^{\circ} \mathrm{C}$ for an hour. Positive colonies (i.e. containing a microsatellite) were identified by hybridization with $(\mathrm{CT})_{10}$ and $(\mathrm{GT})_{10}$ probes labelled with digoxigenine using the DIG Nucleic Acid Detection kit (Boehringer Manheim). Positives clones were picked and stored at $-80{ }^{\circ} \mathrm{C}$ until sequencing. Ninety-six of those clones were sequenced with an ABI377 automated sequencer. Pairs of primers were designed for 10 of these sequences using the PRIMER DESIGNER software (version 2.0, Scientific \& Educational Software, 1990 91).

PCR amplification was carried out in $10 \mu \mathrm{L}$ of reaction mixture containing $1050 \mathrm{ng}$ of template DNA, $0.4 \mu \mathrm{M}$ of each locus-specific primer (see Table 1), $1.67 \mathrm{~mm}$ each dCTP, dGTP, and dTTP, $50 \mu \mathrm{M}$ of dATP, $0.01 \mu \mathrm{L} \alpha^{33 \mathrm{P}-}$ dATP $(10 \mathrm{mCi} / \mathrm{mL}, 3000 \mathrm{Ci} / \mathrm{mmol}), 1.5 \mathrm{~mm}$ of $\mathrm{MgCl}_{2}$, $0.2 \mathrm{mg} / \mathrm{mL}$ BSA (bovine serum albumine), $1 \mu \mathrm{L}$ of $10 \mathrm{X}$ buffer $(10 \mathrm{~mm}$ Tris- $\mathrm{HCl}, 50 \mathrm{~mm}$ KCL and $0.1 \%$ Triton X100) and 0.3 units of Taq DNA polymerase (Promega). PCR cycles followed a 'touchdown' procedure (Don et al. 1991). After an initial denaturing step of $3 \mathrm{~min}$ at $94^{\circ} \mathrm{C}, 10$ cycles were performed, each consisting of $30 \mathrm{~s}$ at $94{ }^{\circ} \mathrm{C}, 30 \mathrm{~s}$ of annealing starting at $60^{\circ} \mathrm{C}$ (or $55^{\circ} \mathrm{C}$, see Table 1) and 
Table 1 Characterization of 10 microsatellite loci in Lysiphlebus testaceipes. Repeat units, GenBank accession number, primer sequences, range of annealing $T^{\circ}$ during the 10 first cycles of the touchdown PCR, clone size in bp, observed number of alleles for the oleander population $\left(N_{o}\right)$, observed $\left(H_{\mathrm{O}}\right)$ and expected $\left(H_{\mathrm{E}}\right)$ heterozygosity per locus for the oleander population (asterisks indicate significant departure from Hardy Weinberg equilibrium tested with Fisher's exact test). Lysi5c4 and Lysi5e1 loci were monomorphic on the screened samples. Despite amplification and polymorphism, results are not reported for the locus LysiF10 because of some uncertainties in allele sizing due to the manual electrophoresis employed in the present study

\begin{tabular}{|c|c|c|c|c|c|c|c|}
\hline Locus ID & $\begin{array}{l}\text { Repeat unit of } \\
\text { cloned allele }\end{array}$ & $\begin{array}{l}\text { GenBank } \\
\text { accession } n^{\circ}\end{array}$ & $\begin{array}{l}\text { Primers }\left(\begin{array}{ll}5^{\prime} & 3^{\prime}\end{array}\right) \\
\text { F: forward } \\
\text { R: reverse }\end{array}$ & $\begin{array}{l}T^{\circ} \text { range } \\
\text { (Celsius) }\end{array}$ & $\begin{array}{l}\text { Clone } \\
\text { size (bp) }\end{array}$ & $N_{o}$ & $H_{\mathrm{E}} / H_{o}$ \\
\hline Lysi5a12 & $(\mathrm{TG})_{9}$ & AY670688 & $\begin{array}{l}\text { F: TTAACTTGCCAAAGTCAATG } \\
\text { R: CAAGTTTGAAAATTGAATTAC }\end{array}$ & $5545^{\circ}$ & 176 & 3 & $0.5 / 0.47$ \\
\hline Lysi1b6 & $(\mathrm{TC})_{3}(\mathrm{TC})_{8}$ & AY670689 & $\begin{array}{l}\text { F: TAGTAATATATCGTTGTGTGAA } \\
\text { R: AATTTGCCTGACGACGC }\end{array}$ & $5545^{\circ}$ & 170 & 3 & $0.43 / 0.37$ \\
\hline Lysi5c4 & $(\mathrm{GT})_{6}$ & AY670690 & $\begin{array}{l}\text { F: TACCTATACAGACATATTCG } \\
\text { R: ACAGTGATCTTTCTTCTCTA }\end{array}$ & $5545^{\circ}$ & 107 & 1 & \\
\hline Lysi5e1 & $(\mathrm{TG})_{10}$ & AY670691 & $\begin{array}{l}\text { F: GCTGCCAACTATACTCTC } \\
\text { R: GGATATATTCTAACTTGTTG }\end{array}$ & $5545^{\circ}$ & 148 & 1 & \\
\hline Lysi6b12 & $(\mathrm{CA})_{10}$ & AY670692 & $\begin{array}{l}\text { F: CATATGAAGAGTAAAGATCG } \\
\text { R: CGATTATTCTAGGTAAAATG }\end{array}$ & $5545^{\circ}$ & 135 & 4 & $0.54 / 0.61$ \\
\hline Lysi6f4 & $(\mathrm{CA})_{8}$ & AY670693 & $\begin{array}{l}\text { F: ACATGTGACTTTGTTTGAGA } \\
\text { R: CAAGATAAAGATCCCCATTC }\end{array}$ & $5545^{\circ}$ & 145 & 5 & $0.71 / 0.72$ \\
\hline Lysi H02 & $(\mathrm{TC})_{10}$ & AY670694 & $\begin{array}{l}\text { F: CTGTTCACGTAGTCAATTGC } \\
\text { R: ACCAGTCACAATCACGATCT }\end{array}$ & $6050^{\circ}$ & 185 & 5 & $0.66 / 0.67$ \\
\hline LysiC1158 & $(\mathrm{TC})_{10}$ & AY670695 & $\begin{array}{l}\text { F: ACAGCAAATTTAAAGG } \\
\text { R: GTGTGGGTATTTATAAG }\end{array}$ & $6050^{\circ}$ & 138 & 2 & $0.44 / 0.39$ \\
\hline LysiC5158 & $(\mathrm{TG})_{50}$ & AY670696 & $\begin{array}{l}\text { F: TAACCTATTGGGAACAGCTA } \\
\text { R: GTGACAAGCCACTGAGACC }\end{array}$ & $6050^{\circ}$ & 222 & 17 & $0.91 / 0.82^{*}$ \\
\hline LysiF10 & $(\mathrm{CT})_{14}$ & AY670697 & $\begin{array}{l}\text { F: CATTGTCTATATGGGTGCAC } \\
\text { R: TGTCCAGAAGGGTTGAATTAA }\end{array}$ & $6050^{\circ}$ & 132 & & \\
\hline
\end{tabular}

decreasing by $1{ }^{\circ} \mathrm{C}$ per cycle, and $30 \mathrm{~s}$ at $72{ }^{\circ} \mathrm{C}$. Additional 25 cycles were run consisting of $30 \mathrm{~s}$ at $94^{\circ} \mathrm{C}, 30 \mathrm{~s}$ at $50{ }^{\circ} \mathrm{C}$ (or $45^{\circ} \mathrm{C}$ ), $30 \mathrm{~s}$ at $72{ }^{\circ} \mathrm{C}$. A final extension step was performed at $72{ }^{\circ} \mathrm{C}$ for $5 \mathrm{~min}$. PCR products were denaturated and electrophoresed on standard DNA sequencing gels.

Among the 10 loci tested, seven gave clear amplifications, were polymorphic, and were therefore chosen for population analysis. PCR conditions and primer sequences are described in Table 1.

Genetic variability analyses were performed with GENEPop Version 3.3 (Raymond \& Rousset 1995). Because of the haplodiploidy of $L$. testaceipes, only females were used in the analysis of heterozygosity. In the oleander population, the number of alleles per locus ranged from one to 17 (Table 1). Expected heterozygosity ranged from 0.43 to 0.91 , and observed heterozygosity from 0.37 to 0.82 . No departure from Hardy Weinberg equilibrium (HWE) was detected except for locus C5158 $\left(P=0.035\right.$, s.e. $\left.<10^{-3}\right)$. Three loci, 6B12, H02 and C5158 displayed significant linkage disequilibrium after sequential Bonferroni correction $\left(P<2.10^{-3}\right.$ and s.e. $<5.10^{-3}$ for each pairwise comparison). In the small sample collected on citrus, neither deviations from Hardy Weinberg (except again for locus C5158, P =
0.024 , s.e. $\left.<2.10^{-3}\right)$ nor linkage equilibria were detected. The two populations were significantly differentiated $(P<$ $\left.10-5 ; F_{\mathrm{ST}}=0.09\right)$ raising the question of whether the host plant or the distance separating the two sites $(c .2 \mathrm{~km})$ was responsible for this differentiation. In conclusion, we found a set of at least seven variable microsatellite loci in L. testaceipes that are potentially useful for population studies.

\section{Acknowledgements}

We thank Jean Yves Rasplus for his crucial enthusiasm at the beginning of this study, and the 'Département Santé des Plantes et Environnement' at INRA for the not less crucial financial support.

\section{References}

Don RH, Cox PT, Wainwright BJ, Baker K, Mattick JS (1991) 'Touchdown' PCR to circumvent spurious priming during gene amplification. Nucleic Acids Research, 19, 4008.

Kijas JMH, Fowler JCS, Garbett CA, Thomas MR (1994) Enrichment of microsatellites from the Citrus genome using biotinylated oligo nucleotide sequences bound to streptavidin coated magnetic particles. Biotechniques, 16, 656662. 
Pike KS, Stary P, Miller T et al. (2000) Aphid parasitoids (Hymenop tera: Braconidae: Aphidiinae) of Northwest USA. Proceedings of the Entomological Society of Washington, 102, 688740.

Raymond M, Rousset F (1995) GENEPOP (version 1.2), a population genetics software for exact tests and ecumenicism. Journal of Heredity, 86, 248249.
Sambrook J, Fritsch E, Maniatis T (1989) Molecular Cloning: a Labor atory Manual. Cold Spring Harbor Laboratory Press, New York. Starý P, Lyon JP, Leclant F (1988) Biocontrol of aphids by the intro duced Lysiphlebus testaceipes (Cress.) (Hym., Aphidiidae) in Mediterranean France. Journal of Applied Entomology Zeitschrift für Angewandte Entomologie, 105, 7487. 